\section{Morphological and Physiological Responses of Spirea Species to Saline Water Irrigation}

\author{
Youping Sun \\ Department of Plants, Soils and Climate, Utah State University, 4820 Old \\ Main Hill, Logan, UT 84322
}

Liqin Li

Huzhou Central Hospital, Huzhou Hospital affiliated with Zhejiang University, 198 Hongqi Road, Huzhou, Zhejiang 31300, China

Yuxiang Wang

College of Grassland and Environmental Sciences, Xinjiang Agricultural University, Number 311 East Nongda Road, Urumqi, Xinjiang 830052, China

\section{Xin Dai \\ Utah Agricultural Experiment Station, Utah State University, 4810 Old Main Hill, Logan, UT 84322}

Additional index words. chlorophyll content, mineral nutrient, photosynthesis, salt tolerance, stomatal conductance, transpiration rate, visual quality

\begin{abstract}
Spirea (Spiraea sp.) plants are popular landscape plants in Utah and the Intermountain West United States. Spiraea betulifolia, S. japonica, S. media, S. nipponica, and $S$. thunbergii were evaluated for salinity tolerance in a greenhouse experiment. Plants were irrigated weekly with a nutrient solution at an electrical conductivity (EC) of $1.2 \mathrm{dS} \cdot \mathrm{m}^{-1}$ (control) or saline solution at an EC of 3.0 or $6.0 \mathrm{dS} \cdot \mathrm{m}^{-1}$ for 8 weeks. At the end of the experiment, all spirea plants survived and retained good visual quality, with average visual scores greater than $4(0=$ dead, $5=$ excellent $)$ when irrigated with saline solution at an EC of $3.0 \mathrm{dS} \cdot \mathrm{m}^{-1}$, with the exception of $S$. thunbergii, which showed slight foliar salt damage and an average visual score of 3.8. When irrigated with saline solution at an EC of $6.0 \mathrm{dS} \cdot \mathrm{m}^{-1}$, all $S$. thunbergii plants died, $S$. media exhibited severe foliar salt damage and an average visual score of 1.5 , and $S$. betulifolia, $S$. japonica, and $S$. nipponica displayed slight-to-moderate foliar salt damage and average visual scores greater than 3 . Regardless of spirea species, shoot dry weight decreased by $20 \%$ and $48 \%$ when irrigated with saline solution at ECs of 3.0 and $6.0 \mathrm{dS} \cdot \mathrm{m}^{-1}$, respectively, compared with the control. Saline solution at an EC of $3.0 \mathrm{dS} \cdot \mathrm{m}^{-1}$ did not affect net photosynthesis $\left(P_{n}\right)$ of all spirea species except $S$. nipponica, but saline solution at an EC of $6.0 \mathrm{dS} \cdot \mathrm{m}^{-1}$ decreased the $P_{n}$ of all species by $36 \%$ to $60 \%$. There were $37,7,36,21$, and 104 times more sodium $\left(\mathrm{Na}^{+}\right)$ concentrations in leaf and 29, 28, 28, 13, and 69 times more chloride $\left(\mathrm{Cl}^{-}\right)$concentrations in leaf than in the control when $S$. betulifolia, $S$. japonica, $S$. media, $S$. nipponica, and $S$. thunbergii were irrigated with saline solution at an EC of $6.0 \mathrm{dS} \cdot \mathrm{m}^{-1}$. Correlation analyses indicated that foliar salt damage and reduced plant growth and photosynthesis were induced mainly by $\mathrm{Cl}^{-}$ions accumulated in the spirea leaves. $S$. thunbergii was the most sensitive species; it had high mortality and low visual quality at both salinity levels. Spiraea japonica, $S$. nipponica, and $S$. betulifolia were relatively more tolerant and had good visual quality at elevated salinity compared with $S$. media and $S$. thunbergii. These research results are valuable for growers and landscape professionals during plant selection for nursery production using low-quality water and landscapes in salt-prone areas.
\end{abstract}

In the arid and semi-arid southwestern United States, salinity is becoming one of the most serious problems threatening the quality of urban landscapes. High salinity in the soil and irrigation water affects plant growth, development, and survival (Munns and Tester, 2008). As salinity stress becomes severe, plants experience foliar damage, such as leaf burn, scorch, necrosis, and premature defoliation (Munns and Tester, 2008). As a result of excessive $\mathrm{Na}^{+}$and $\mathrm{Cl}^{-}$absorption, plants usually exhibit reduced photosynthesis and stomatal conductance $\left(g_{\mathrm{S}}\right)$ and nutrient landscapes in salt-prone regions. Additional research-based information regarding salinity tolerance is needed for widely used landscape plants.

Spiraea is the largest genus in Rosaceae (rose family), with more than 100 species of shrubs native to the northern temperate hemisphere and great diversity in eastern Asia (Khan et al., 2016). Many species in the genus Spiraea are used extensively as ornamental plants in temperate climates, particularly for their showy clusters of dense flowers. In the United States, an estimated \$29 million of spirea plants are sold annually for garden and landscape uses, making them the fourth-bestselling deciduous shrubs (U.S. Department of Agriculture, 2015). Numerous spirea species, hybrids, and cultivars with various flower colors (white, pink, or dark red) and foliage colors (yellow, blue, green, or variegated foliage) are selected from natural populations and breeding efforts in gardens for landscape use (Dirr, 2009).

Efforts have been made to investigate the responses of spirea plants to abiotic stresses. For example, Stanton and Mickelbart (2014) evaluated the water stress responses of Spiraea alba (meadowsweet) and Spiraea tomentosa (steeplebush) under greenhouse conditions and found that both species had reduced growth, transpiration, and predawn water potential, but that they exhibited the ability to osmotically adjust to low soil water content to maintain water uptake and reduce water loss. Salt tolerance of spirea species has also been reported, but the results are inconsistent. For example, $S$. japonica and Spiraea $\times$ bumalda (bumald spirea) were considered to be tolerant, moderately tolerant, or sensitive to saline soils or salt spray in different publications (Appleton et al., 2015; Beckerman and Lerner, 2009; Jull, 2009). These reports have been made on the basis of anecdotal observations without scientific research approaches. Therefore, a systematic approach is needed to evaluate different spirea species for salinity tolerance. Wang et al. (2019a) recently evaluated seven Japanese spirea cultivars in a greenhouse and reported that all Japanese spirea cultivars were moderately sensitive to the salinity levels at an EC of 3.0 and $6.0 \mathrm{dS} \cdot \mathrm{m}^{-1}$. The fact that many spirea species with diversified salt tolerance are planted in gardens and landscapes merits further investigation. This study aimed to quantify the growth, morphological, and physiological responses of five spirea species to a range of salinity levels in a greenhouse setting.

imbalance, especially calcium deficiency (Munns and Tester, 2008). Salt-tolerant plants have a better ability to adjust internally to the osmotic effects of high salinity levels than salt-sensitive plants. It is noted that substantial differences in salt tolerance exist among various landscape plant species (Navarro et al., 2008). It is possible to identify salt-tolerant landscape plants by investigating their specific morphological and physiological responses to salinity stress. Using salt-tolerant plants would prevent salt damage and maintain aesthetically appealing

\section{Materials and Methods}

Plant materials and growing conditions. Spiraea betulifolia 'Tor Gold' (Glow Girl ${ }^{\circledR}$ ), S. media 'SMSMBK' (Double Play ${ }^{\circledR}$ Blue Kazoo $^{\circledR}$ USPP 26,655), S. nipponica 'SMNSNFD' (Wedding Cake ${ }^{\circledR}$ USPP 28,096), S. japonica 'SMNSJMFR' (Double Play ${ }^{\circledR}$ Red USPP 26,993), and S. thunbergii 'Ogon' were used in this study. This research was conducted at the same time following the same protocol as previously reported by Wang et al. (2019a) 
for seven Japanese spirea cultivars. In brief, rooted cuttings in 32-cell $(5.5 \times 5.5 \times 10.0 \mathrm{~cm})$ trays were donated by Spring Meadow Nursery (Grand Haven, MI) on 2 Mar. 2018. Three weeks later, plants were transplanted into 1gallon injection-molded polypropylene containers (PC1D-4; Nursery Supplies, Orange, CA). A peat-based soilless growing substrate that consisted of $75 \%$ peatmoss (Canadian sphagnum peatmoss; SunGro Horticulture Canada, Agawam, MA), 25\% vermiculite (Therm-O-Rock West, Chandler, AZ), 24.3 $\mathrm{g} \cdot \mathrm{ft}^{-3}$ white athletic field marking gypsum (92\% calcium sulfate dehydrate, $21 \%$ calcium, $17 \%$ sulfur; Western Mining and Minerals, Bakersfield, CA) was used. All plants were watered with tap water (Table 1) before the experiment. They were grown in a greenhouse at ambient air temperatures of $26.2 / 19.6{ }^{\circ} \mathrm{C} \pm$ $1.9 / 5.0{ }^{\circ} \mathrm{C}$ day/night; the average daily light integral was $17.5 \pm 3.6 \mathrm{~mol} \cdot \mathrm{m}^{-2} \cdot \mathrm{d}^{-1}$ during the experimental period. From 1 Mar. to 2 May, 1000-W high-pressure sodium lamps (Hydrofarm, Petaluma, CA) provided supplemental lights at light intensities of $223 \pm 37 \mu \mathrm{mol} \cdot \mathrm{m}^{-2} \cdot \mathrm{s}^{-1}$ at the canopy level when light intensity was less than $544 \mu \mathrm{mol} \cdot \mathrm{m}^{-2} \cdot \mathrm{s}^{-1}$ inside the greenhouse. These lights also provided a $16-\mathrm{h}$ photoperiod from 0600 to $2200 \mathrm{HR}$.

Treatments. On 27 Apr. 2018 (4 weeks after transplanting), all plants were pruned to $\approx 15 \mathrm{~cm}$ tall. From 2 May 2018 to 14 June

Received for publication 13 Jan. 2020. Accepted for publication 3 Apr. 2020

Published online 6 May 2020.

This research was supported in part by the United States Department of Agriculture (USDA) National Institute of Food and Agriculture (NIFA) Hatch project UTA01381 and USDA Specialty Crop Block Grant Program (\#202715), New Faculty Start-Up Funds from the Office of Research and Graduate Studies, and the Center for Water-Efficient Landscaping at Utah State University. This research was also supported by the Utah Agricultural Experiment Station, Utah State University, and approved as journal paper no. 9312. We are grateful for the in-kind support of plant materials from Spring Meadow Nursery (Grand Haven, MI), chloride analyses by Christina Perez, mineral analyses by Chaoyi Deng, and valuable comments from anonymous reviewers. We appreciate the financial support from National Modern Agricultural Technology \& Industry System (CARS-34) of China and National Natural Science Foundation of China (\#31860675) to Yuxiang Wang and National Natural Science Foundation of China (\#31600255) to Liqin $\mathrm{Li}$ as visiting scholars at Utah State University, Logan, UT.

The content is solely the responsibility of the authors and does not necessarily represent the official views of the funding agencies. Mention of a trademark, proprietary product, or vendor does not constitute a guarantee or warranty of the product by the USDA and the American Society for Horticultural Science, and does not imply its approval to the exclusion of other products or vendors that also may be suitable.

Y.S. is the corresponding author. E-mail: youping. sun@usu.edu.

This is an open access article distributed under the CC BY-NC-ND license (https://creativecommons.org/ licenses/by-nc-nd/4.0/).
2018, plants were irrigated weekly with a nutrient solution at an EC of $1.2 \mathrm{dS} \cdot \mathrm{m}^{-1}$ (control) or saline solution at an EC of 3.0 or $6.0 \mathrm{dS} \cdot \mathrm{m}^{-1}$ at $1 \mathrm{~L}$ per pot resulting in a leaching fraction of $\approx 33.6 \% \pm 16.7 \%$. Between treatment solution irrigations, a total of $300 \mathrm{~mL}$ of nutrient solution was applied to avoid the additive effects of dry substrate. Water-soluble fertilizer $(15 \mathrm{~N}-2.2 \mathrm{P}-12.5 \mathrm{~K}$ and Peters Excel 15-5-15 Ca-Mag Special; ICL Specialty Fertilizers, Dublin, $\mathrm{OH}$ ) at $0.8 \mathrm{~g} \cdot \mathrm{L}^{-1}$ was dissolved in tap water to create the nutrient solution (control) (Table 1). Sodium chloride $(\mathrm{NaCl})$ and calcium chloride $\left(\mathrm{CaCl}_{2}\right)$ were supplemented in the nutrient solution to create saline solutions (Table 1). Usually, $\mathrm{NaCl}$ is found in reclaimed water (Niu and Cabrera. 2010), but $\mathrm{CaCl}_{2}$ is added to prevent potential calcium deficiencies (Carter and Grieve, 2006). The ECs of all nutrient and saline solutions were confirmed using an EC meter (LAQUA Twin; Horiba, Kyoto, Japan) before use, and $\mathrm{pH}$ was adjusted to $6.5 \pm 0.2$ using $1 \mathrm{M}$ nitric acid. When treatment solutions were applied, leachate solution of one plant per treatment per species was collected using pour-through techniques described by Cavins et al. (2008) and Wright (1986). The ECs of the leachate solution were measured and averaged across species. In addition, a saturated soil paste technique (Gavlak et al., 1994) was modified to determine the final substrate EC of the saturated soil extract (ECe). After harvest, containers with substrate were air-dried in the greenhouse for 2 weeks, and the top substrate $(\approx 2-3 \mathrm{~cm})$ of three plants per treatment per species was sampled for soil extraction. Tebuconazole (Bayer Advanced, Research Triangle Park, NC) at $0.6 \mathrm{~mL} /$ gallon was sprayed on all plants to control powdery mildew as needed.

Plant growth and visual quality. On 25 June 2018, plant shoots were harvested and the leaf areas (square centimeter) of each of the seven plants were measured using an area meter (LI-3100; LI-COR Biosciences, Lincoln, NE). One week before harvest, the plant height (centimeters), two canopy diameters at perpendicular directions (width 1 and width 2 , centimeters), and the number of inflorescences of each of seven plants were recorded. The growth index was calculated as (height + width $1+$ width 2)/3 (Wu et al., 2016). At harvest, visual quality was rated for each of seven plants based on a 5-point scale (visual score), where $0=$ dead, $1=$ severe foliar salt damage ( $>90 \%$ leaves with burn and necrosis at the leaf margin), $2=$ moderate foliar salt damage $(50 \%$ to $90 \%), 3=$ slight foliar salt damage (less than 50\%), 4 = good quality with minimal foliar salt damage, and $5=$ excellent without foliar salt damage (Wang et al., 2019a). Visual quality between the scales was rated by the researcher using one decimal. Shoot dry weight was recorded after plant shoots were dried in an oven at $70{ }^{\circ} \mathrm{C}$ for $3 \mathrm{~d}$.

Leaf relative chlorophyll content and gas exchange. Soil plant analysis development (SPAD) readings were performed using a handheld chlorophyll meter (SPAD-502
Plus; Minolta Camera Co., Osaka, Japan) at 1 week before harvest. The averaged SPAD values of five mature and healthy leaves on each of seven plants were recorded to represent the leaf relative chlorophyll content. Gas exchange was measured on four plants per species per treatment on 19 and 20 June (sunny days) using a portable photosynthesis system (CIRAS-3; PP Systems, Amesbury, MA) with an automatic universal broadleaf cuvette (PLC6; PP Systems). Leaf $\mathrm{P}_{\mathrm{n}}, g_{\mathrm{S}}$, and transpiration rate $(E)$ were recorded between 1000 and $1400 \mathrm{HR}$ at a $P P F$ density of 1000 $\mu \mathrm{mol} \cdot \mathrm{m}^{-2} \cdot \mathrm{s}^{-1}, \mathrm{CO}_{2}$ concentration of 400 $\mu \mathrm{mol} \cdot \mathrm{mol}^{-1}$, and leaf temperature of $25^{\circ} \mathrm{C}$ in the cuvette.

Mineral analysis. Four plants per species per treatment were selected to analyze leaf $\mathrm{Na}^{+}, \mathrm{Cl}^{-}$, calcium $\left(\mathrm{Ca}^{2+}\right)$, and potassium $\left(\mathrm{K}^{+}\right)$ concentrations. Dried tissue was ground using a stainless Thomas-Wiley laboratory mill (Model 4; Thomas Scientific, Swedesboro, NJ) with a 1-mm screen. Powder samples were analyzed following the protocols described by Wang et al. (2019b). Sodium, $\mathrm{Ca}^{2+}$, and $\mathrm{K}^{+}$concentrations were analyzed using an inductively coupled plasma-optical emission spectrometer (Perkin-Elmer Optima $4300 \mathrm{DV}$; Shelton, CT), whereas the $\mathrm{Cl}^{-}$ concentration was determined using a M926 Chloride Analyzer (Cole Parmer Instrument Company, Vernon Hills, IL).

Experiment design and statistical analysis. The experiment used a completely randomized design with seven plants per species per treatment. A two-way analysis of variance was performed for all plant growth parameters. Leaf area, $E$, and $g_{\mathrm{S}}$ were analyzed as lognormal distributed data, and the number of inflorescences was analyzed as negative binomial data. A first-order autoregressive covariance structure was used for the weekly repeated measures of the visual score over the course of 8 weeks. Means separation among treatments and species was adjusted using Tukey's method for multiplicity at $\alpha=$ 0.05 . All statistical analyses were performed with PROC GLIMMIX procedures of SAS/STAT 14.3 in SAS (version 9.4; SAS Institute, Cary, NC). Correlation analyses were also conducted for leaf $\mathrm{Na}^{+}$and $\mathrm{Cl}^{-}$concentrations and visual scores, growth, and gas exchange data using JMP (version 13.2; SAS Institute).

\section{Results and Discussion}

Visual score. Saline irrigation water impacted plant visual quality with various responses among spirea species $(P<0.001)$ (Table 2). Plant visual quality was also affected by the length of the exposure to salinity stress $(P<0.001)$. At 2 weeks after the initiation of treatment, no spirea species exhibited any visible foliar salt damage (burn and necrosis at the leaf margin) except $S$. thunbergii plants that experienced slight-tomoderate foliar salt damage and had an average visual score of 2.9 when irrigated with saline solution at an EC of $6.0 \mathrm{dS} \cdot \mathrm{m}^{-1}$ (Table 3). At 4 weeks, $S$. japonica still had 
Table 1. Chemical compositions of tap water, nutrient solution, and saline solution used in the study.

\begin{tabular}{lccrr}
\hline & & Nutrient solution $^{\mathrm{x}}$ & \multicolumn{2}{c}{ Saline solution $^{\mathrm{w}}$} \\
\cline { 4 - 5 } $\mathrm{Item}^{\mathrm{z}}$ & Tap water & EC 3 & EC 6 \\
\hline $\mathrm{Ca}^{2+}\left(\mathrm{mg} \cdot \mathrm{L}^{-1}\right)$ & 47.2 & 86.4 & 307.3 & 619.3 \\
$\mathrm{Mg}^{2+}\left(\mathrm{mg} \cdot \mathrm{L}^{-1}\right)$ & 17.3 & 31.7 & 41.0 & 40.9 \\
$\mathrm{Na}^{+}\left(\mathrm{mg} \cdot \mathrm{L}^{-1}\right)$ & 1.4 & 1.35 & 208.2 & 514.2 \\
$\mathrm{SO}_{4}{ }^{2-}\left(\mathrm{mg} \cdot \mathrm{L}^{-1}\right)$ & 8.9 & 10.8 & 8.3 & 8.8 \\
$\mathrm{Cl}^{-}\left(\mathrm{mg} \cdot \mathrm{L}^{-1}\right)$ & 3.4 & 5 & 689.0 & 1730.0 \\
$\mathrm{~B}\left(\mathrm{mg} \cdot \mathrm{L}^{-1}\right)$ & 0 & 0.21 & 0.1 & 0.15 \\
Sodium adsorption ratio (SAR) & 0.04 & 0.06 & 2.95 & 5.39 \\
Adjusted SAR & 0.09 & 0.11 & 6.80 & 13.70 \\
EC $\left(\mathrm{dS} \cdot \mathrm{m}^{-1}\right)$ & 0.37 & $1.19 \pm 0.04$ & $3.15 \pm 0.07$ & $6.15 \pm 0.14$ \\
\hline
\end{tabular}

${ }^{\mathrm{z}}$ Calcium $\left(\mathrm{Ca}^{2+}\right)$, magnesium $\left(\mathrm{Mg}^{2+}\right)$, sodium $\left(\mathrm{Na}^{+}\right)$, sulphate $\left(\mathrm{SO}_{4}^{2-}\right)$, chloride $\left(\mathrm{Cl}^{-}\right)$, and boron (B) ions

${ }^{\mathrm{y}}$ Adopted from Wang et al. (2019b).

${ }^{\mathrm{x}} \mathrm{A}$ nutrient solution at an electrical conductivity (EC) of $1.2 \mathrm{dS} \cdot \mathrm{m}^{-1}$ (control) was prepared by adding 0.8 g. $\mathrm{L}^{-1}$ water-soluble fertilizer $(15 \mathrm{~N}-2.2 \mathrm{P}-12.5 \mathrm{~K}$; Peters Excel 15-5-15 Cal-Mag Special) to the tap water ${ }^{\mathrm{w}}$ Saline solution at an EC of $3.0 \mathrm{dS} \cdot \mathrm{m}^{-1}$ (EC 3) was created by adding $0.46 \mathrm{~g} \cdot \mathrm{L}^{-1}$ sodium chloride $(\mathrm{NaCl})$ and $0.44 \mathrm{~g} \cdot \mathrm{L}^{-1}$ calcium chloride $\left(\mathrm{CaCl}_{2}\right)$ to the nutrient solution, whereas $1.25 \mathrm{~g} \cdot \mathrm{L}^{-1} \mathrm{NaCl}$ and $1.20 \mathrm{~g} \cdot \mathrm{L}^{-1}$ $\mathrm{CaCl}_{2}$ were added to the nutrient solution to create saline solution at an EC of $6.0 \mathrm{dS} \cdot \mathrm{m}^{-1}$ (EC 6).

Table 2. Summary of the analysis of variance for the effects of electrical conductivity (EC) of saline solutions, plant species, and their interactions on EC of the soil extract (ECe), visual score at week 8, growth index, leaf area, shoot dry weight (DW), relative chlorophyll content [soil plant analysis development (SPAD) reading], net photosynthesis $\left(\mathrm{P}_{\mathrm{n}}\right)$, stomatal conductance $\left(g_{\mathrm{S}}\right)$, and transpiration rate $(E)$ of spirea (Spiraea $\mathrm{sp}$.) species irrigated with a nutrient solution at an EC of $1.2 \mathrm{dS} \cdot \mathrm{m}^{-1}$ (control) or a saline solution at an EC of $3.0 \mathrm{dS} \cdot \mathrm{m}^{-1}$ (EC 3) or $6.0 \mathrm{dS} \cdot \mathrm{m}^{-1}$ (EC 6) in a greenhouse. ${ }^{2}$

\begin{tabular}{|c|c|c|c|c|c|c|c|c|c|}
\hline \multirow[b]{2}{*}{ Source } & \multicolumn{9}{|c|}{ Analysis of variance } \\
\hline & $\begin{array}{l}\text { Soil } \\
\text { ECe }^{y}\end{array}$ & $\begin{array}{l}\text { Visual } \\
\text { score }\end{array}$ & $\begin{array}{l}\text { Growth } \\
\text { index }\end{array}$ & $\begin{array}{l}\text { Leaf } \\
\text { area }\end{array}$ & $\begin{array}{c}\text { Shoot } \\
\text { DW }\end{array}$ & SPAD & $P_{n}$ & $g_{\mathrm{S}}$ & $E$ \\
\hline Species & NS & $* * *$ & $* * *$ & $* * *$ & $* * *$ & $* * *$ & $* * *$ & $* * *$ & $* * *$ \\
\hline $\mathrm{EC}$ & $* * *$ & $* * *$ & $* * *$ & $* * *$ & $* * *$ & $* * *$ & $* * *$ & $* *$ & $* *$ \\
\hline Species $\times$ EC & $* *$ & $* * *$ & $* * *$ & $* *$ & NS & $* * *$ & $*$ & NS & NS \\
\hline
\end{tabular}

${ }^{\mathrm{z}}$ Saline solution was created by adding sodium chloride $(\mathrm{NaCl})$ and calcium chloride $\left(\mathrm{CaCl}_{2}\right)$ to the nutrient solution.

${ }^{\mathrm{y}}$ Soil ECe was collected using a saturated soil paste technique (Gavlak et al., 1994) with some modifications.

NS, $* * *, * * *$ Nonsignificant or significant at $P<0.05,0.01$, or 0.001 , respectively

no obvious foliar salt damage, and S. betulifolia, S. media, and S. nipponica exhibited minimal foliar salt damage when irrigated with saline solution at an EC of $6.0 \mathrm{dS} \cdot \mathrm{m}^{-1}$. However, all $S$. thunbergii plants died at an EC of $6.0 \mathrm{dS} \cdot \mathrm{m}^{-1}$; even at an EC of $3.0 \mathrm{dS} \cdot \mathrm{m}^{-1}$, S. thunbergii showed minimal foliar salt damage. At 6 weeks, the only spirea species that showed any visible foliar salt damage were $S$. betulifolia and $S$. thunbergii, which had minimal foliar salt damage and average visual scores of 4.6 and 4.4, respectively, when irrigated with saline solution at an EC of 3.0 $\mathrm{dS} \cdot \mathrm{m}^{-1}$. Spiraea betulifolia, S. japonica, and $S$. nipponica plants irrigated with saline solution at an EC of $6.0 \mathrm{dS} \cdot \mathrm{m}^{-1}$ still showed good visual quality, with minimal foliar salt damage and average visual scores greater than 4.0; however, S. media had slight-to-moderate foliar salt damage, with an average visual score of 2.9 , and all $S$. thunbergii plants exposed to this treatment died.

At 8 weeks, $S$. japonica plants irrigated with saline solution at an EC of $3.0 \mathrm{dS} \cdot \mathrm{m}^{-1}$ still had no foliar salt damage, and S. betulifolia, S. media, and S. nipponica plants displayed minimal foliar salt damage, with average visual scores greater than 4.4 (Table 3 ). With this treatment, $S$. thunbergii plants had slight foliar salt damage, with an average visual score of 3.8. When irrigated with saline solution at an EC of $6.0 \mathrm{dS} \cdot \mathrm{m}^{-1}$, one out of seven S. betulifolia and $S$. media plants died, and the remain- ing $S$. media plants had severe foliar salt damage, with an average visual score of 1.5; however, $S$. betulifolia, $S$. japonica, and $S$. nipponica plants had slight-to-moderate foliar salt damage, with average visual scores of 3.3 to 3.6. These visual quality results suggested that $S$. thunbergii was the species most sensitive to salinity levels in this study, followed by $S$. media, $S$. betulifolia, and $S$. nipponica; however, $S$. japonica was the most tolerant among all five species tested.

Foliar salt damage was observed during our previous study of seven $S$. japonica cultivars (Wang et al., 2019a). Marosz (2004) reported that $S$. ×cinerea 'Grefsheim' had severe foliar salt damage; $33 \%$ of plants died at an EC of $12.0 \mathrm{dS} \cdot \mathrm{m}^{-1}$, but all plants survived at an EC of $6.0 \mathrm{dS} \cdot \mathrm{m}^{-1}$. The visual quality of $S$. japonica decreased dramatically at ECs of 3.7 to $6.5 \mathrm{dS} \cdot \mathrm{m}^{-1}$, and $50 \%$ of plants died at an EC of $6.5 \mathrm{dS} \cdot \mathrm{m}^{-1}$ (Chen et al., 2019). The foliar salt damage might result from high salt levels accumulated in the growing substrate. Actually, the average leachate EC increased from 0.88 to $3.63 \mathrm{dS} \cdot \mathrm{m}^{-1}$ when plants were irrigated with the nutrient solution (Fig. 1), whereas saline solution at ECs of 3.0 and $6.0 \mathrm{dS} \cdot \mathrm{m}^{-1}$ resulted in average leachate EC levels that increased from 1.66 to $7.01 \mathrm{dS} \cdot \mathrm{m}^{-1}$ and from 2.96 to $10.36 \mathrm{dS} \cdot \mathrm{m}^{-1}$, respectively. More directly, the ECe levels of the substrate increased as the salinity level of the irrigation water increased $(P<0.001)$ (Table 2, Fig. 2$)$.
Compared with the control, the ECe values of the substrate increased by $2,1,1,1$, and 3 times for $S$. betulifolia, $S$. japonica, $S$. media, $S$. nipponica, and $S$. thunbergii, respectively, when irrigated with saline solution at an EC of $3.0 \mathrm{dS} \cdot \mathrm{m}^{-1}$ and by $3,1,4,4$, and 9 times for $S$. betulifolia, $S$. japonica, $S$. media, $S$. nippon$i c a$, and $S$. thunbergii, respectively, when irrigated with saline solution at an EC of 6.0 $\mathrm{dS} \cdot \mathrm{m}^{-1}$. Visual quality is critically important to marketing ornamental plants. Salt damage should be limited to produce high-quality plants during nursery production. Best management practices should be adopted to reduce salt accumulation in the peat-based growing substrate, especially when poor-quality water is used for irrigation, such as monitoring irrigation water quality, using high-drainage substrate, and increasing leachate fraction (Altland et al., 2014).

Growth data. There were significant interactive effects between the saline solution treatment and spirea species for the growth index $(P<0.001)$ and leaf area $(P=0.003)$, but not for shoot dry weight $(P=0.14)$ (Table 2). Saline solution at an EC of 3.0 $\mathrm{dS} \cdot \mathrm{m}^{-1}$ did not affect the growth index of all spirea species except for $S$. media and $S$. nipponica (Table 4). Compared with the control, the growth index of $S$. media and $S$. nipponica was reduced by $12 \%$ and $11 \%$, respectively, when irrigated with saline solution at an EC of $3.0 \mathrm{dS} \cdot \mathrm{m}^{-1}$. Saline solution at an EC of $6.0 \mathrm{dS} \cdot \mathrm{m}^{-1}$ did not affect the growth index of $S$. japonica compared with the control, but $S$. betulifolia, $S$. media, and $S$. nipponica had reductions of $14 \%$ to $30 \%$ in the growth index. All spirea species irrigated with saline solution at an EC of $3.0 \mathrm{dS} \cdot \mathrm{m}^{-1}$ had leaf areas similar to those of the control, with the exception of $S$. media, which had a reduction of $33 \%$ (Table 4 ). Compared with the control, saline solution at an EC of 6.0 $\mathrm{dS} \cdot \mathrm{m}^{-1}$ decreased the leaf area of all species by $37 \%$ to $76 \%$. Saline solutions affected the growth of spirea, as indicated by the reduced shoot dry weight $(P<0.001)$ (Table 2$)$. On average, the shoot dry weights of all spirea species irrigated with saline solution at ECs of 3.0 and $6.0 \mathrm{dS} \cdot \mathrm{m}^{-1}$ were reduced by $20 \%$ and $48 \%$, respectively (Fig. 3). Spiraea japonica produced the greatest shoot dry weight among the five spirea species tested, indicating differences in growth habits.

These results suggest that salinity stress slows plant growth and development, which has been previously reported by multiple studies (Chen et al., 2017; Liu et al., 2017; Niu et al., 2013; Sun et al., 2015; Wang et al., 2019b; Wu et al., 2016). For example, Wang et al. (2019a) observed that seven $S$. japonica cultivars irrigated with saline solution at ECs of 3.0 and $6.0 \mathrm{dS} \cdot \mathrm{m}^{-1}$ had $4 \%$ and $12 \%$ reductions in the growth index, respectively, compared with the control (EC, $\left.1.2 \mathrm{dS} \cdot \mathrm{m}^{-1}\right)$. They also found that shoot dry weights of seven $S$. japonica cultivars were reduced by $2 \%$ to $35 \%$ and by $35 \%$ to $56 \%$, respectively, when fertigated with saline solution at ECs of 3.0 and $6.0 \mathrm{dS} \cdot \mathrm{m}^{-1}$ compared with the control. Chen et al. (2019) reported that S. japonica had 
Table 3. Visual score of spirea (Spiraea sp.) species irrigated with a nutrient solution at an electrical conductivity (EC) of $1.2 \mathrm{dS} \cdot \mathrm{m}^{-1}$ (control) or a saline solution at an EC of $3.0 \mathrm{dS} \cdot \mathrm{m}^{-1}(\mathrm{EC} 3)$ or $6.0 \mathrm{dS} \cdot \mathrm{m}^{-1}$ (EC 6$)$ in a greenhouse. ${ }^{\mathrm{z}}$

\begin{tabular}{|c|c|c|c|c|c|c|c|c|c|c|c|c|}
\hline \multirow{2}{*}{ Species } & \multicolumn{12}{|c|}{ Visual score ${ }^{\mathrm{y}}$} \\
\hline & \multicolumn{3}{|c|}{2 weeks } & \multicolumn{3}{|c|}{4 weeks } & \multicolumn{3}{|c|}{6 weeks } & \multicolumn{3}{|c|}{8 weeks } \\
\hline S. betulifolia & $5.0 \mathrm{a}^{\mathrm{x}} \mathrm{A}^{\mathrm{w}}$ & $5.0 \mathrm{aA}$ & $5.0 \mathrm{aA}$ & $5.0 \mathrm{aA}$ & $5.0 \mathrm{aA}$ & $4.8 \mathrm{bA}$ & $5.0 \mathrm{aA}$ & $4.6 \mathrm{bB}$ & $4.1 \mathrm{cAB}$ & $5.0 \mathrm{aA}$ & $4.4 \mathrm{bB}$ & $3.3 \mathrm{cA}$ \\
\hline S. media & $5.0 \mathrm{aA}$ & $5.0 \mathrm{aA}$ & $5.0 \mathrm{aA}$ & $5.0 \mathrm{aA}$ & $5.0 \mathrm{aA}$ & $4.7 \mathrm{bA}$ & $5.0 \mathrm{aA}$ & $5.0 \mathrm{aA}$ & $2.9 \mathrm{bC}$ & $5.0 \mathrm{aA}$ & $4.8 \mathrm{bAB}$ & $1.5 \mathrm{cB}$ \\
\hline S. nipponica & $5.0 \mathrm{aA}$ & $5.0 \mathrm{aA}$ & $5.0 \mathrm{aA}$ & $5.0 \mathrm{aA}$ & $5.0 \mathrm{aA}$ & $4.8 \mathrm{bA}$ & $5.0 \mathrm{aA}$ & $5.0 \mathrm{aA}$ & $4.0 \mathrm{bB}$ & $5.0 \mathrm{aA}$ & 4.7 bB & $3.3 \mathrm{cA}$ \\
\hline S. thunbergii & $5.0 \mathrm{aA}$ & $5.0 \mathrm{aA}$ & $2.9 \mathrm{bB}$ & $5.0 \mathrm{aA}$ & $4.8 \mathrm{bB}$ & $0.2 \mathrm{cB}$ & $4.9 \mathrm{aB}$ & $4.4 \mathrm{bB}$ & $0 \mathrm{cD}$ & $5.0 \mathrm{aA}$ & $3.8 \mathrm{bC}$ & $0 \mathrm{cB}$ \\
\hline
\end{tabular}

${ }^{\mathrm{z}}$ Saline solution was created by adding sodium chloride $(\mathrm{NaCl})$ and calcium chloride $\left(\mathrm{CaCl}_{2}\right)$ to the nutrient solution.

${ }^{\mathrm{y}_{0}}=$ dead; $1=$ severe $(>90 \%$ ) foliar salt damage (burn and necrosis at the leaf margin); $2=$ moderate $(50 \%$ to $90 \%)$ foliar salt damage; $3=$ slight $(<50 \%)$ foliar salt damage; 4 = good quality with minimal foliar salt damage; and 5 = excellent without foliar salt damage (Wang et al., 2019a).

'Means with the same lowercase letters within 1 week and within a row are not significantly different among treatments according to Tukey's method for multiplicity at $\alpha=0.05$.

${ }^{\text {w}}$ Means with the same uppercase letters within 1 week and within a column are not significantly different among species according to Tukey's method for multiplicity at $\alpha=0.05$.

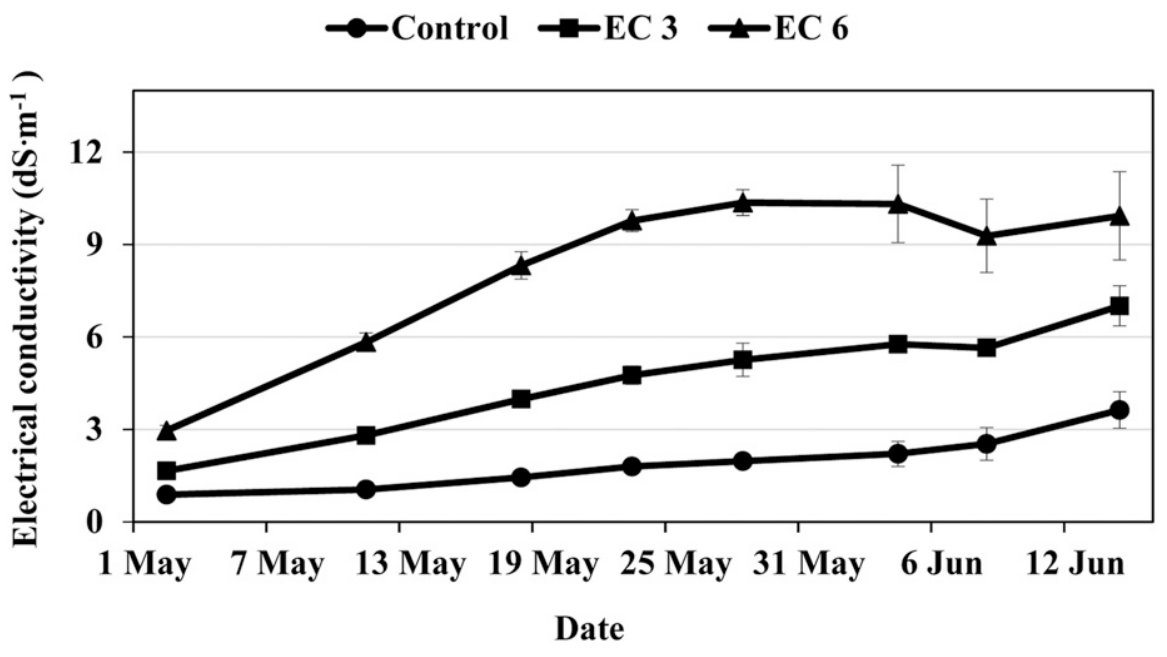

Fig. 1. Time course of the leachate electrical conductivity (EC) during the experimental period. The control represents a nutrient solution at an EC of $1.2 \mathrm{dS} \cdot \mathrm{m}^{-1}$. EC 3 represents a saline solution at an EC of $3.0 \mathrm{dS} \cdot \mathrm{m}^{-1}$. EC 6 represents a saline solution at an EC of $6.0 \mathrm{dS} \cdot \mathrm{m}^{-1}$. Vertical bars represent the SE of five measurements (one per species).

a reduction of $56 \%$ in the growth index at an EC of $6.5 \mathrm{dS} \cdot \mathrm{m}^{-1}$ and lost $50 \%$ of its shoot dry weight at an EC of $4.6 \mathrm{dS} \cdot \mathrm{m}^{-1}$ compared with the control (EC, $\left.0.9 \mathrm{dS} \cdot \mathrm{m}^{-1}\right)$. Marosz (2004) found that the mean shoot length of $S . \times$ cinerea 'Grefsheim' at an EC of $12.0 \mathrm{dS} \cdot \mathrm{m}^{-1}$ was reduced by $30 \%$ compared with the control (EC, $0.5 \mathrm{dS} \cdot \mathrm{m}^{-1}$ ). Marosz (2004) also reported that $S$. $\times$ cinerea 'Grefsheim' irrigated with saline solution at an EC of $12.0 \mathrm{dS} \cdot \mathrm{m}^{-1}$ had $70 \%$ to $78 \%$ reductions in the shoot fresh weight compared with ECs of $0.5,1.5,3.0$, and $6.0 \mathrm{dS} \cdot \mathrm{m}^{-1}$.

In addition, $S$. betulifolia, $S$. media, $S$. nipponica, and $S$. thunbergii did not bloom throughout the experimental period. Compared with the control, the number of inflorescences of $S$. japonica was reduced by $48 \%$ when irrigated with saline solution at an EC of $6.0 \mathrm{dS} \cdot \mathrm{m}^{-1}$, but it did not change at an EC of $3.0 \mathrm{dS} \cdot \mathrm{m}^{-1}$ (data not shown). Reductions in the number of inflorescences of plants under salinity stress have been documented in multiple studies (Niu et al., 2013; Sun et al., 2015; Wang et al., 2019b; Wu et al., 2016). Wang et al. (2019a) reported that $S$. japonica 'Galen', 'Minspi', and 'SMNSJMFP' had decreased numbers of inflorescences by $39 \%$ to $50 \%$ when irrigated with saline solu- tion at an EC of $6.0 \mathrm{dS} \cdot \mathrm{m}^{-1}$ compared with the control (EC, $1.2 \mathrm{dS} \cdot \mathrm{m}^{-1}$ ). Chen et al. (2019) observed that $S$. japonica irrigated with saline solution at an EC of $6.5 \mathrm{dS} \cdot \mathrm{m}^{-1}$ exhibited $84 \%$ fewer inflorescences compared with the control (EC, 0.9 dS $\cdot \mathrm{m}^{-1}$ ). Furthermore, $S$. $\times$ cinerea 'Grefsheim' irrigated with saline solution at an EC of $12.0 \mathrm{dS} \cdot \mathrm{m}^{-1}$ decreased its number of inflorescences by $89 \%$ to $92 \%$ compared with saline solutions at ECs of 0.5,

Leaf relative chlorophyll content. Significant interactive effects occurred between the saline solution treatment and spirea species for the relative chlorophyll content $(P<$ 0.001 ) (Table 2). Compared with the control, the SPAD readings were reduced by $11 \%$, $11 \%, 33 \%$, and $33 \%$ for $S$. japonica, $S$. nipponica, $S$. betulifolia, and S. media, respectively, when they were irrigated with saline solution at an EC of $6.0 \mathrm{dS} \cdot \mathrm{m}^{-1}$ (Table 5); however, that of $S$. betulifolia, $S$. media, S. nipponica, and $S$. thunbergii did not change when irrigated with saline solution at an EC of $3.0 \mathrm{dS} \cdot \mathrm{m}^{-1}$. Similarly, Wang et al. (2019a) reported that saline solution at ECs of 3.0 and $6.0 \mathrm{dS} \cdot \mathrm{m}^{-1}$ reduced the SPAD readings of $S$. japonica 'Minspi', 'NCSX2', 1.5, 3.0, and $6.0 \mathrm{dS} \cdot \mathrm{m}^{-1}$ (Marosz, 2004).
'SMNSJMFP', and 'Yan' compared with the control (EC, $1.2 \mathrm{dS} \cdot \mathrm{m}^{-1}$ ). Chen et al. (2019) documented that the SPAD readings of $S$. japonica declined $\approx 35 \%$ at an EC of 6.5 $\mathrm{dS} \cdot \mathrm{m}^{-1}$ compared with the control (EC, 0.9 $\left.\mathrm{dS} \cdot \mathrm{m}^{-1}\right)$. All these results consistently indicate that the relative chlorophyll content decreased as the salinity level of irrigation water increased.

Based on the visual quality, growth, or morphology data, S. japonica, S. nipponica, and $S$. betulifolia exhibited more salinity tolerance compared with $S$. media and $S$. thunbergii. Among the five spirea species, $S$. thunbergii was the most sensitive species and had higher mortality and lower visual quality at both salinity levels. Like other $S$. japonica cultivars (Wang et al., 2019a), all five spirea species tested are moderately sensitive to salt stress, as indicated by the increased foliar salt damage and reduced growth index, leaf area, shoot dry weight, number of inflorescences, and relative chlorophyll content at the salinity levels tested in this study.

Gas exchange. There were interactive effects between saline solution treatment and spirea species for $\mathrm{P}_{\mathrm{n}}(P=0.05)$ (Table 2). All spirea species irrigated with saline solution at an EC of $3.0 \mathrm{dS} \cdot \mathrm{m}^{-1}$ had $P_{n}$ similar to those of the control, except for $S$. nipponica, in which the $\mathrm{P}_{\mathrm{n}}$ was reduced by $37 \%$ (Table 5). Saline solution at an EC of 6.0 $\mathrm{dS} \cdot \mathrm{m}^{-1}$ further reduced $\mathrm{P}_{\mathrm{n}}$ by $58 \%, 36 \%$, and $60 \%$, respectively, in $S$. betulifolia, $S$. japon$i c a$, and $S$. nipponica, but in for $S$. media. Similarly, the $\mathrm{P}_{\mathrm{n}}$ of seven $S$. japonica cultivars was reduced by $41 \%$ to $56 \%$ at an EC of $6.0 \mathrm{dS} \cdot \mathrm{m}^{-1}$ compared with those reduced at an EC of $1.2 \mathrm{dS} \cdot \mathrm{m}^{-1}$ (Wang et al., 2019a). Chen et al. (2019) observed that $S$. japonica had a $39 \%$ reduction of $\mathrm{P}_{\mathrm{n}}$ when irrigated with saline solution at an EC of $5.7 \mathrm{dS} \cdot \mathrm{m}^{-1} \mathrm{com}$ pared with those reduced at an EC of 0.9 $\mathrm{dS} \cdot \mathrm{m}^{-1}$. Saline solution irrigation also impacted spirea $E$ and $g_{\mathrm{S}}$ with similar responses among species (Table 2). Regardless of species, a significant decrease of $38 \%$ in $E$ and $45 \%$ in $g_{\mathrm{S}}$ was observed when saline solution at an EC of $6.0 \mathrm{dS} \cdot \mathrm{m}^{-1}$ was used to irrigate spirea plants (Fig. 4). The $E$ and $g_{\mathrm{S}}$ of $S$. japonica, $S$. nipponica, and $S$. thunbergii 
Control $=\mathrm{EC} 3$ EC 6

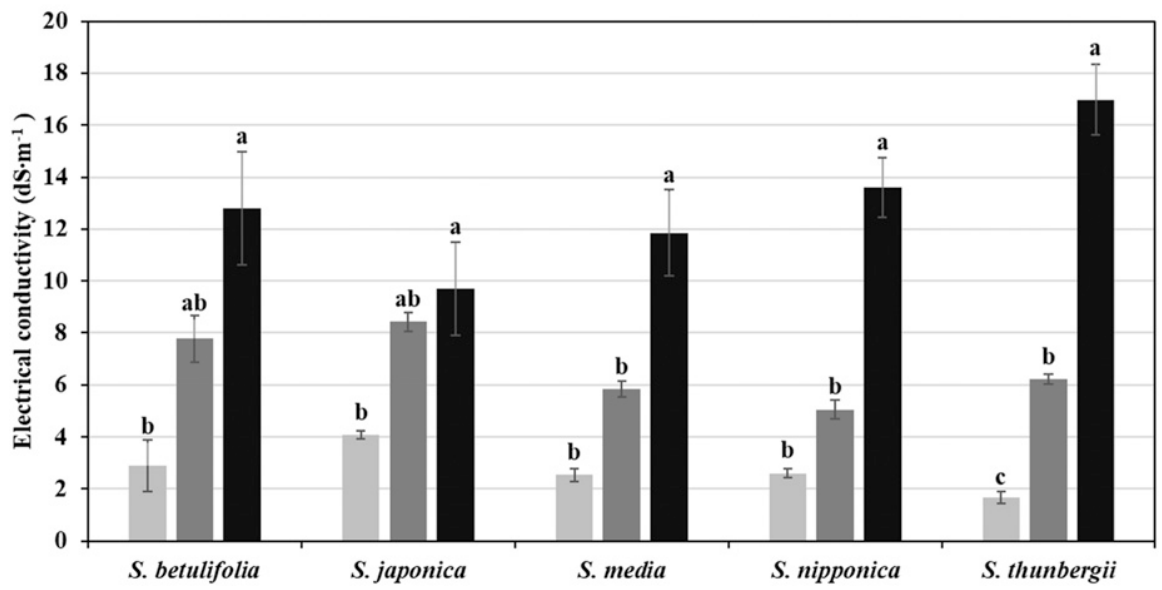

Fig. 2. Electrical conductivity (EC) of the soil extraction recorded for five spirea (Spiraea sp.) species irrigated with a nutrient solution at an EC of $1.2 \mathrm{dS} \cdot \mathrm{m}^{-1}$ (control) or a saline solution at an EC of 3.0 $\mathrm{dS} \cdot \mathrm{m}^{-1}$ (EC 3) or $6.0 \mathrm{dS} \cdot \mathrm{m}^{-1}$ (EC 6). Vertical bars represent the SE of three measurements. The same lowercase letters above columns within species represent no significance among treatments according to Tukey's method for multiplicity at $\alpha=0.05$.

Table 4. Growth index and leaf area of spirea (Spiraea sp.) species irrigated with a nutrient solution at an electrical conductivity (EC) of $1.2 \mathrm{dS} \cdot \mathrm{m}^{-1}$ (control) or a saline solution at an EC of $3.0 \mathrm{dS} \cdot \mathrm{m}^{-1}$ (EC 3) or $6.0 \mathrm{dS} \cdot \mathrm{m}^{-1}$ (EC 6$)$ in a greenhouse. ${ }^{2}$

\begin{tabular}{lccccccc}
\hline & \multicolumn{3}{c}{ Growth index $(\mathrm{cm})^{\mathrm{y}}$} & & \multicolumn{3}{c}{ Leaf area $\left(\mathrm{cm}^{2}\right)$} \\
\cline { 2 - 4 } \cline { 7 - 8 } Species & Control & EC 3 & EC 6 & & Control & EC 3 & EC 6 \\
\hline S. betulifolia & $26.1 \mathrm{ab}^{\times} \mathrm{B}^{\mathrm{w}}$ & $28.8 \mathrm{aB}$ & $24.7 \mathrm{bC}$ & & $810.4 \mathrm{aBC}$ & $677.4 \mathrm{aB}$ & $490.3 \mathrm{aB}$ \\
S. japonica & $40.2 \mathrm{aA}$ & $41.6 \mathrm{aA}$ & $40.8 \mathrm{aA}$ & & $3224.5 \mathrm{aA}$ & $3026.2 \mathrm{aA}$ & $1787.8 \mathrm{bA}$ \\
S. media & $37.6 \mathrm{aA}$ & $32.8 \mathrm{bB}$ & $26.2 \mathrm{cC}$ & & $1055.1 \mathrm{aB}$ & $722.8 \mathrm{bB}$ & $257.5 \mathrm{cC}$ \\
S. nipponica & $38.0 \mathrm{aA}$ & $33.7 \mathrm{bB}$ & $30.7 \mathrm{bB}$ & & $649.1 \mathrm{aC}$ & $607.1 \mathrm{aB}$ & $255.9 \mathrm{bC}$ \\
S. thunbergii & $40.2 \mathrm{aA}$ & $35.0 \mathrm{aAB}$ & - $^{\mathrm{v}}$ & & $900.1 \mathrm{aBC}$ & $689.2 \mathrm{aB}$ & - $^{\mathrm{v}}$ \\
\hline
\end{tabular}

${ }^{\mathrm{z}}$ Saline solution was created by adding sodium chloride $(\mathrm{NaCl})$ and calcium chloride $\left(\mathrm{CaCl}_{2}\right)$ to the nutrient solution.

${ }^{\mathrm{y}}$ Growth index $=($ height + width $1+$ width 2$) / 3($ Wu et al., 2016).

${ }^{\mathrm{x}}$ Means with the same lowercase letters within dependent variables and within a row are not significantly different among treatments according to Tukey's method for multiplicity at $\alpha=0.05$.

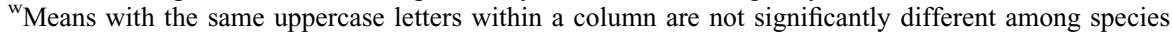
according to Tukey's method for multiplicity at $\alpha=0.05$.

${ }^{v}$ All $S$. thunbergii plants died when irrigated with a saline solution at an EC of $6.0 \mathrm{dS} \cdot \mathrm{m}^{-1}$.

were greater than that of $S$. betulifolia and $S$. media. There was no correlation between EC levels of irrigation water and the $E$ of $S$. japonica (Chen et al., 2019). The $E$ and $g_{\mathrm{S}}$ of $S$. japonica plants irrigated with saline solution at an EC of $3.0 \mathrm{dS} \cdot \mathrm{m}^{-1}$ were similar to that in the control; however, saline irrigation water at an EC of $6.0 \mathrm{dS} \cdot \mathrm{m}^{-1}$ reduced $E$ and $g_{\mathrm{S}}$ of $S$. japonica by $38 \%$ and $14 \%$, respectively (Wang et al., 2019a). It is important to highlight that reductions in $E$ and $g_{\mathrm{S}}$ have been reported as a salinity tolerance mechanism, decreasing water consumption and salt accumulation in the shoot (Taiz and Zeiger, 2015). The results of this study suggest that good adaptability to high-salt environments enables $S$. japonica, the most salt-tolerant species among the five spirea species tested, to maintain adequate biomass and vitality.

Mineral nutrients. Saline water irrigation impacted the leaf $\mathrm{Na}^{+}$and $\mathrm{Cl}^{-}$concentrations of all five spirea species tested, with different responses among species (Table 6). Among the spirea species, $S$. betulifolia plants absorbed the greatest amount of $\mathrm{Na}^{+}$ions (4.84 $\left.\mathrm{mg} \cdot \mathrm{g}^{-1}\right)$ when irrigated with saline so- lution at an EC of $3.0 \mathrm{dS} \cdot \mathrm{m}^{-1}$, with 12 times more $\mathrm{Na}^{+}$ions accumulated in the leaves than in the control (Table 6). The leaf $\mathrm{Na}^{+}$concentrations of the other four spirea species irrigated with saline solution at an EC of 3.0 $\mathrm{dS} \cdot \mathrm{m}^{-1}$ were not statistically different from the control, but they tended to increase. Furthermore, the leaf $\mathrm{Na}^{+}$concentrations of $S$. betulifolia, S. japonica, S. media, S. nipponica, and $S$. thunbergii irrigated with saline solution at an EC of $6.0 \mathrm{dS} \cdot \mathrm{m}^{-1}$ were, respectively, 37, 7, 36, 21, and 104 times greater than those of the respective controls. Similar results indicating that the leaf $\mathrm{Na}^{+}$concentration increased with increasing salinity levels of irrigation water have been reported by Chen et al. (2017), Liu et al. (2017), Niu et al. (2013), Sun et al. (2015), and Wu et al. (2016). However, Marosz (2004) observed that $\mathrm{Na}^{+}$uptake of $S$. × cinerea 'Grefsheim' irrigated with $\mathrm{NaCl}$ solutions five times per year at 7-day intervals was similar among all salinity levels (ECs of 1.5, 3.0, 6.0, and $\left.12.0 \mathrm{dS} \cdot \mathrm{m}^{-1}\right)$. The discrepancy in the leaf $\mathrm{Na}^{+}$ concentrations in these studies might be attributed to the high-drainage sandy loam soil used by Marosz (2004), which resulted in soil solution ECs less than $1.6 \mathrm{dS} \cdot \mathrm{m}^{-1}$ during the entire study. In our experiment, a lowdrainage peat-based soilless substrate was used, and salts significantly accumulated (Figs. 1 and 2). Different plant species and durations of saline water irrigation also might have partially led to the discrepancies in leaf $\mathrm{Na}^{+}$concentrations in these studies.

Compared with the control, $S$. media, $S$. nipponica, and $S$. thunbergii had 10, 4, and 15 times more $\mathrm{Cl}^{-}$ions in the leaves, respectively, when irrigated with saline solution at an EC of $3.0 \mathrm{dS} \cdot \mathrm{m}^{-1}$ (Table 6). The actual $\mathrm{Cl}^{-}$ concentrations in the leaves of $S$. betulifolia and $S$. japonica irrigated with saline solution at an $\mathrm{EC}$ of $3.0 \mathrm{dS} \cdot \mathrm{m}^{-1}$ were 6 and 5 times greater than that of the control, respectively, but still not statistically different. The $\mathrm{Cl}^{-}$ concentrations in leaves of $S$. betulifolia, $S$. japonica, S. media, S. nipponica, and $S$. thunbergii further increased 29, 28, 28, 13, and 69 times, respectively, when irrigated with saline solution at an EC of $6.0 \mathrm{dS} \cdot \mathrm{m}^{-1}$. These results again demonstrated the fact that leaf $\mathrm{Cl}^{-}$concentrations increased with increasing salinity levels of irrigation water (Chen et al., 2017; Liu et al., 2017; Niu et al., 2013; Sun et al., 2015; Wu et al., 2016), although the magnitude of the increase in leaf $\mathrm{Cl}^{-}$concentrations varied among plant species, duration of saline water irrigation, and growing substrate.

Leaf $\mathrm{Na}^{+}$and $\mathrm{Cl}^{-}$concentrations correlated negatively with visual scores recorded after 8 weeks of treatment $(P=0.008$ and $P<$ 0.001 , respectively, for $\mathrm{Na}^{+}$and $\left.\mathrm{Cl}^{-}\right)$. In addition, there were negative correlations between leaf $\mathrm{Na}^{+}$concentrations and the growth index $(P=0.03)$, as well as between leaf $\mathrm{Cl}^{-}$concentrations and the growth index $(P=0.03)$, shoot dry weight $(P=0.05), \mathrm{P}_{\mathrm{n}}$ $(P=0.02), E(P=0.05)$, and $g_{\mathrm{S}}(P=0.02)$. No significant correlations were observed among leaf $\mathrm{Na}^{+}$concentrations and leaf area, shoot dry weight, $\mathrm{SPAD}, \mathrm{P}_{\mathrm{n}}, E$, and $g_{\mathrm{S}}(P>0.07)$, or among leaf $\mathrm{Cl}^{-}$concentrations and leaf area and SPAD $(P>0.1)$. These correlations indicated that $\mathrm{Cl}^{-}$ions accumulated in the spirea leaves imposed more deleterious influences on visual quality, plant growth and development, and gas exchange compared with $\mathrm{Na}^{+}$ions. High $\mathrm{Na}^{+}$and/or $\mathrm{Cl}^{-}$accumulations in plant leaves have reportedly caused leaf damage and inhibited photosynthesis (Taiz and Zeiger, 2015). The leaf $\mathrm{Cl}^{-}$contents in this study are high enough to cause salt damage to the spirea plants and inhibit plant photosynthesis. Leaf $\mathrm{Na}^{+}$concentrations are also high enough to damage spirea foliage, but they might not be enough to decrease plant photosynthesis.

The leaf $\mathrm{Ca}^{2+}$ concentrations were impacted interactively by increasing salinity levels and spirea species (Table 6). S. nipponica and $S$. thunbergii had $38 \%$ and $58 \%$ more $\mathrm{Ca}^{2+}$ ions, respectively, in leaves than the control when they were irrigated with saline solution at an EC of $3.0 \mathrm{dS} \cdot \mathrm{m}^{-1}$, but there was no statistical difference in the other three species (Table 6). The leaf $\mathrm{Ca}^{2+}$ concentrations of all spirea species irrigated with saline solution at an EC of $6.0 \mathrm{dS} \cdot \mathrm{m}^{-1}$ were 


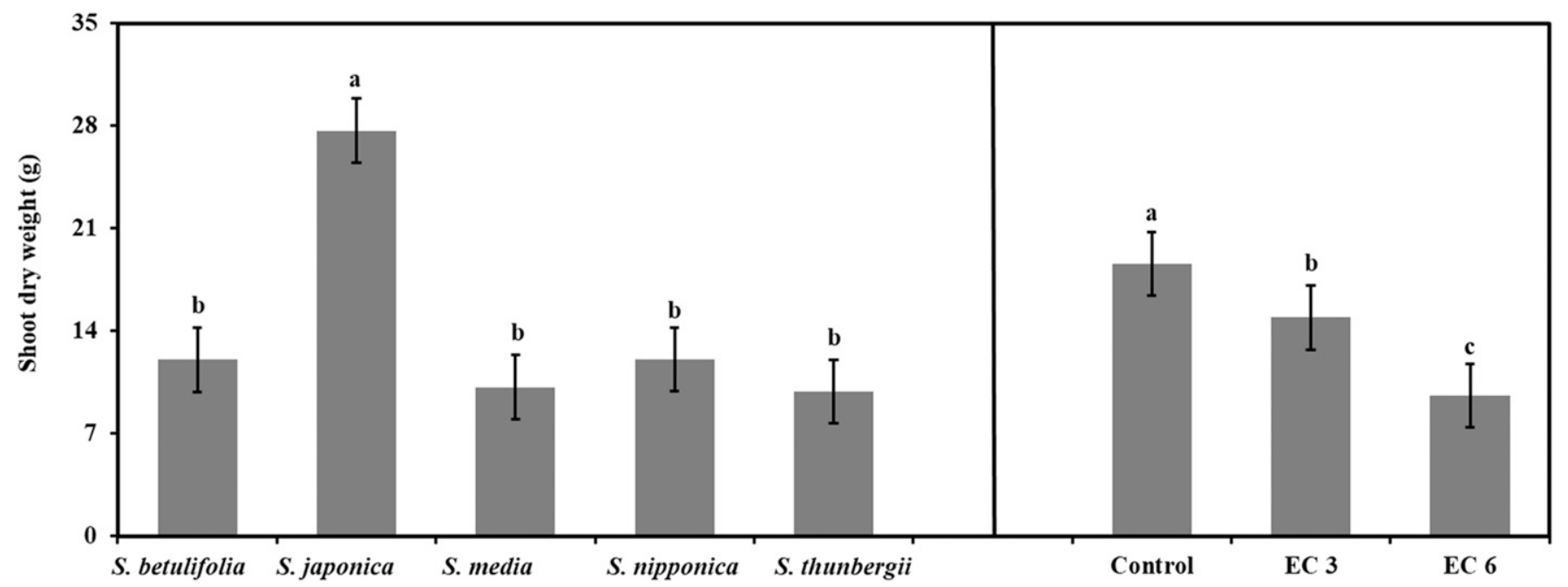

Fig. 3. Shoot dry weight of spirea (Spiraea sp.) species irrigated with a nutrient solution at an electrical conductivity (EC) of $1.2 \mathrm{dS} \cdot \mathrm{m}^{-1}$ (control) or a saline solution at an EC of $3.0 \mathrm{dS} \cdot \mathrm{m}^{-1}$ (EC 3) or $6.0 \mathrm{dS} \cdot \mathrm{m}^{-1}$ (EC 6) in a greenhouse. Vertical bars represent the SE of 21 and 35 measurements for plant species and saline solution treatment, respectively. The same lowercase letters above columns represent no significance among plant species or saline solution treatments according to Tukey's method for multiplicity at $\alpha=0.05$.

Table 5. Relative chlorophyll content (SPAD) and net photosynthesis $\left(\mathrm{P}_{\mathrm{n}}\right)$ of spirea (Spiraea sp.) species irrigated with a nutrient solution at an electrical conductivity (EC) of $1.2 \mathrm{dS} \cdot \mathrm{m}^{-1}$ (control) or a saline solution at an EC of $3.0 \mathrm{dS} \cdot \mathrm{m}^{-1}$ (EC 3$)$ or $6.0 \mathrm{dS} \cdot \mathrm{m}^{-1}$ (EC 6) in a greenhouse. ${ }^{\mathrm{z}}$

\begin{tabular}{|c|c|c|c|c|c|c|}
\hline \multirow[b]{2}{*}{ Species } & \multicolumn{3}{|c|}{ SPAD } & \multicolumn{3}{|c|}{$\mathrm{P}_{\mathrm{n}}\left(\mu \mathrm{mol} \cdot \mathrm{m}^{-2} \cdot \mathrm{s}^{-1}\right)$} \\
\hline & Control & EC 3 & EC 6 & Control & EC 3 & EC 6 \\
\hline S. betulifolia & $17.1 \mathrm{a}^{\mathrm{y}} \mathrm{C}^{\mathrm{x}}$ & $18.0 \mathrm{aD}$ & $11.5 \mathrm{bD}$ & $5.9 \mathrm{aC}$ & $5.6 \mathrm{aB}$ & $2.5 \mathrm{bB}$ \\
\hline S. japonica & $39.7 \mathrm{aB}$ & $36.6 \mathrm{bC}$ & $35.5 \mathrm{bB}$ & $9.5 \mathrm{aAB}$ & $9.3 \mathrm{aA}$ & $6.1 \mathrm{bA}$ \\
\hline S. media & $42.6 \mathrm{aB}$ & $43.0 \mathrm{aB}$ & $28.6 \mathrm{bC}$ & $4.1 \mathrm{aC}$ & $3.6 \mathrm{aC}$ & $2.5 \mathrm{aB}$ \\
\hline S. nipponica & $62.2 \mathrm{aA}$ & $60.3 \mathrm{aA}$ & $55.2 \mathrm{bA}$ & $10.4 \mathrm{aA}$ & $6.5 \mathrm{bAB}$ & $3.7 \mathrm{cAB}$ \\
\hline S. thunbergii & $10.8 \mathrm{aD}$ & $8.7 \mathrm{aE}$ & ${ }^{\mathrm{w}}$ & $6.6 \mathrm{aBC}$ & $5.3 \mathrm{aBC}$ & ${ }^{\mathrm{w}}$ \\
\hline
\end{tabular}

${ }^{\mathrm{z}}$ Saline solution was created by adding sodium chloride $(\mathrm{NaCl})$ and calcium chloride $\left(\mathrm{CaCl}_{2}\right)$ to the nutrient solution.

${ }^{y}$ Means with same lowercase letters within dependent variables and within a row are not significantly different among treatments by Tukey's method for multiplicity at $\alpha=0.05$.

${ }^{x}$ Means with same uppercase letters within a column are not significantly different among species by Tukey's method for multiplicity at $\alpha=0.05$.

${ }^{\mathrm{w}}$ All $S$. thunbergii plants died when irrigated with a saline solution at an EC of $6.0 \mathrm{dS} \cdot \mathrm{m}^{-1}$.

$28 \%$ to $90 \%$ greater than that of the control. Similarly, as soil salinity increased, more $\mathrm{Ca}^{2+}$ ions were taken by $S$. xinerea 'Grefsheim' (Marosz, 2004). The actual $\mathrm{Ca}^{2+}$ concentrations in the spirea leaves in our experiment are similar to those in Berberis thunbergii (japanese barberry) (Chen et al., 2017), Diervilla rivularis (mountain bushhoneysuckle), Forsythia $\times$ intermedia 'Mindor' (border forsythia) (Liu et al., 2017), Salvia farinacea 'Henry Duelberg' ('Henry Duelberg' salvia), Verbena $\times$ hybrida 'Blue Princess' ('Blue Princess' verbena) (Sun et al., 2015), Scabiosa columbaria (butterfly blue), Caryopteris $\times$ clandonensis 'Dark Knight' ('Dark knight' bluebeard), and Cestrum 'Orange Peel' (orange peel jessamine) (Wu et al., 2016), although all these plant species were irrigated with saline solutions at ECs of 5.0 and $10.0 \mathrm{dS} \cdot \mathrm{m}^{-1}$. The magnitude of the change in $\mathrm{Ca}^{2+}$ ions in the spirea leaves was less than that of $\mathrm{Na}^{+}$ions, which might result from the fact that sodium salts can decrease the availability and mobility of $\mathrm{Ca}^{2+}$ ions as well as their transport to plant shoot (Grattan and Grieve, 1999). Another reason is that $\mathrm{NaCl}$ and $\mathrm{CaCl}_{2}$ (at a molar ratio of 2:1) were used to create the saline solution in this study. No visible $\mathrm{Ca}^{2+}$ deficiency symptom was observed during the experiment, although $\mathrm{Ca}^{2+}$ deficiency usually occurs in plants grown in salt stress conditions as a result of decreased availability, transport, and mobility of $\mathrm{Ca}^{2+}$ to the plant (Grattan and Grieve, 1999). This study shows that adding $\mathrm{CaCl}_{2}$ to the irrigation solution could ameliorate $\mathrm{Ca}^{2+}$ deficiency for plants under the condition of salinity stress dominated by sodium salts.

Saline water irrigation affected $\mathrm{K}^{+}$concentrations in leaves of spirea species, and the responses varied among species (Table 6). Compared with the control, leaf $\mathrm{K}^{+}$concentrations of $S$. betulifolia irrigated with saline solution at ECs of 3.0 and $6.0 \mathrm{dS} \cdot \mathrm{m}^{-1}$ decreased by $22 \%$ and $29 \%$, respectively (Table 6 ). Decreased $\mathrm{K}^{+}$content was also noted in leaves of $S$. Xcinerea 'Grefsheim' at an EC of 12.0 $\mathrm{dS} \cdot \mathrm{m}^{-1}$ (Marosz, 2004). There was no significance among treatments regarding leaf $\mathrm{K}^{+}$ concentrations of $S$. japonica. However, $S$. media, S. nipponica, and $S$. thunbergii irrigated with saline solution at an EC of $3.0 \mathrm{dS} \cdot \mathrm{m}^{-1}$ had leaf $\mathrm{K}^{+}$concentrations similar to that of the control, but their leaf $\mathrm{K}^{+}$concentrations increased by $14 \%, 17 \%$, and $59 \%$, respectively, when irrigated with saline solution at an EC of $6.0 \mathrm{dS} \cdot \mathrm{m}^{-1}$. These results are in line with previous observations of leaf $\mathrm{K}^{+}$concentrations in Cuphea hyssopifolia (Mexican false heather) (Wu et al., 2016), Phlox paniculata (phlox) (Sun et al., 2015), Chaenomeles speciose (flowering quince), Diervilla rivularis, Hibiscus syriacus 'ILVOPS' (rose of Sharon), and Forsythia Xintermedia 'Mindor' (Liu et al., 2017). Potassium may transport against a strong $\mathrm{Na}^{+}$concentration gradient to increase the osmotic adjustment to protect plants from salt stress (Grattan and Grieve, 1999; Taiz and Zeiger, 2015).

Increasing salinity levels also affected the $\mathrm{Mg}^{2+}, \mathrm{P}, \mathrm{Zn}^{2+}, \mathrm{Mn}^{2+}$, and $\mathrm{Cu}^{2+}$ concentrations in the leaves of spirea species (Table 6). All spirea species irrigated with saline solution at an EC of $3.0 \mathrm{dS} \cdot \mathrm{m}^{-1}$ had leaf $\mathrm{Mg}^{2+}$ concentrations similar to that of the control, with the exception of $S$. japonica, which had a reduction of $26 \%$ compared with the control (Table 6). When irrigated with saline solution at an EC of $6.0 \mathrm{dS} \cdot \mathrm{m}^{-1}$, leaf $\mathrm{Mg}^{2+}$ concentrations of $S$. betulifolia and $S$. nipponica were not statistically different from that of the control, but the leaf $\mathrm{Mg}^{2+}$ concentrations decreased by $21 \%$ and $14 \%$, respectively, in $S$. japonica and $S$. media, and increased by $60 \%$ in $S$. thunbergii. All spirea species irrigated with saline solution at an EC of $3.0 \mathrm{dS} \cdot \mathrm{m}^{-1}$ had leaf $\mathrm{P}$ concentrations similar to that of the control, with the exception of $S$. betulifolia, which had a 39\% greater P concentration than the control (Table 6). When irrigated with saline solution at an EC of 6.0 $\mathrm{dS} \cdot \mathrm{m}^{-1}$, the leaf $\mathrm{P}$ concentrations increased by $21 \%$ and $69 \%$ in $S$. betulifolia and $S$. thunbergii, respectively, but decreased by $12 \%$ in $S$. nipponica, whereas the leaf $\mathrm{P}$ concentrations of $S$. japonica and $S$. media were similar to that of the control.

Irrespective of the spirea species, saline solution at ECs of 3.0 and $6.0 \mathrm{dS} \cdot \mathrm{m}^{-1}$ increased $\mathrm{Zn}^{2+}$ concentrations by $36 \%$ and $95 \%$, respectively, increased $\mathrm{Mn}^{2+}$ concentrations by $75 \%$ and $102 \%$, respectively, and 

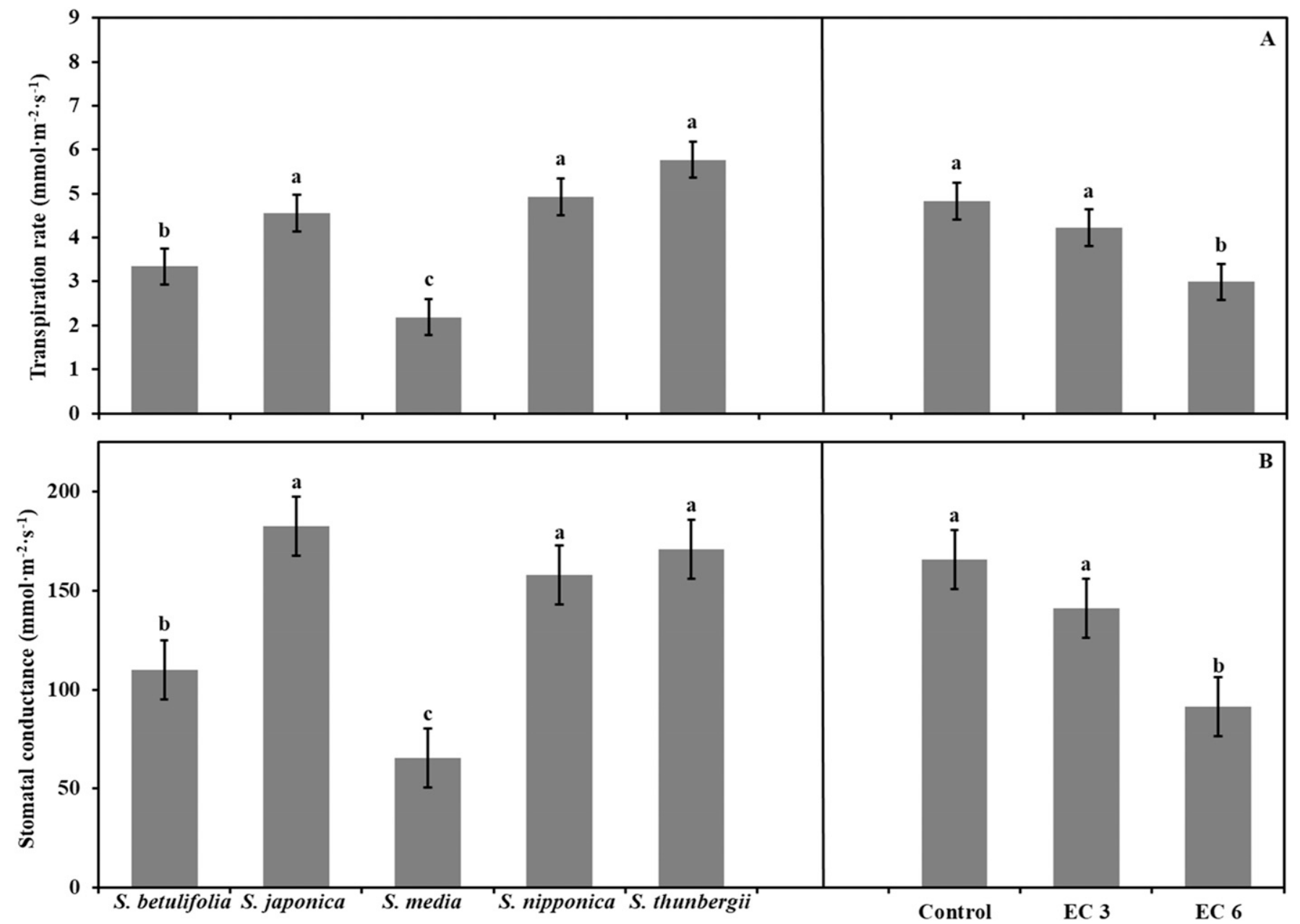

Fig. 4. Stomatal conductance $\left(g_{\mathrm{S}}\right)$ and transpiration rate $(E)$ of spirea (Spiraea sp.) species irrigated with a nutrient solution at an electrical conductivity (EC) of 1.2 $\mathrm{dS} \cdot \mathrm{m}^{-1}$ (control) or a saline solution at an EC of $3.0 \mathrm{dS} \cdot \mathrm{m}^{-1}$ (EC 3) or $6.0 \mathrm{dS} \cdot \mathrm{m}^{-1}$ (EC 6) in a greenhouse. Vertical bars represent the SE of 12 and 20 measurements for plant species and saline solution treatment, respectively. The same lowercase letters above columns represent no significance among plant species or saline solution treatments according to Tukey's method for multiplicity at $\alpha=0.05$.

Table 6. Macronutrients and micronutrients of spirea (Spiraea sp.) species irrigated with a nutrient solution at an electrical conductivity (EC) of 1.2 dS. $\mathrm{m}^{-1}$ (control) or a saline solution at an EC of $3.0 \mathrm{dS} \cdot \mathrm{m}^{-1}$ (EC 3) or $6.0 \mathrm{dS} \cdot \mathrm{m}^{-1}$ (EC 6) in a greenhouse. ${ }^{2}$

\begin{tabular}{|c|c|c|c|c|c|c|c|c|c|c|c|}
\hline \multirow[b]{2}{*}{ Species } & \multirow[b]{2}{*}{ Treatment } & \multicolumn{10}{|c|}{ Mineral concn (mg. ${ }^{-1}$ dry wt) } \\
\hline & & $\mathrm{Na}^{+}$ & $\mathrm{Ca}^{2+}$ & $\mathrm{Cl}^{-}$ & $\mathrm{K}^{+}$ & $\mathrm{Mg}^{2+}$ & $\mathrm{P}$ & $\mathrm{S}$ & $\mathrm{Zn}^{2+}$ & $\mathrm{Mn}^{2+}$ & $\mathrm{Cu}^{2+}$ \\
\hline \multirow[t]{2}{*}{ S. betulifolia } & Control & $0.38 \mathrm{c}^{\mathrm{y}}$ & $10.29 \mathrm{~b}$ & $0.92 \mathrm{~b}$ & $15.32 \mathrm{a}$ & $3.47 \mathrm{a}$ & $3.93 \mathrm{~b}$ & $2.35 \mathrm{a}$ & $0.04 \mathrm{~b}$ & $0.77 \mathrm{~b}$ & $0.00 \mathrm{a}$ \\
\hline & EC 3 & $4.84 \mathrm{~b}$ & $12.61 \mathrm{~b}$ & $6.89 \mathrm{~b}$ & $11.94 \mathrm{~b}$ & $3.60 \mathrm{a}$ & $5.46 \mathrm{a}$ & $2.45 \mathrm{a}$ & $0.06 \mathrm{a}$ & $1.34 \mathrm{a}$ & $0.00 \mathrm{a}$ \\
\hline \multirow[t]{3}{*}{ S. japonica } & Control & $0.32 \mathrm{~b}$ & $11.37 \mathrm{~b}$ & $0.57 \mathrm{~b}$ & $22.80 \mathrm{a}$ & $4.39 \mathrm{a}$ & $5.48 \mathrm{a}$ & $2.20 \mathrm{a}$ & $0.04 \mathrm{~b}$ & $0.41 \mathrm{c}$ & $0.00 \mathrm{a}$ \\
\hline & EC 3 & $0.76 \mathrm{ab}$ & $11.74 \mathrm{~b}$ & $3.36 \mathrm{~b}$ & $23.46 \mathrm{a}$ & $3.24 \mathrm{~b}$ & $6.49 \mathrm{a}$ & $2.15 \mathrm{a}$ & $0.04 \mathrm{ab}$ & $0.69 \mathrm{~b}$ & $0.00 \mathrm{a}$ \\
\hline & EC 6 & $2.70 \mathrm{a}$ & $14.56 \mathrm{a}$ & $16.65 \mathrm{a}$ & $21.55 \mathrm{a}$ & $3.48 \mathrm{~b}$ & $5.88 \mathrm{a}$ & $2.18 \mathrm{a}$ & $0.05 \mathrm{a}$ & $1.06 \mathrm{a}$ & $0.00 \mathrm{a}$ \\
\hline S. media & Control & $0.09 \mathrm{~b}$ & $13.66 \mathrm{~b}$ & $0.87 \mathrm{c}$ & $18.64 \mathrm{ab}$ & $5.77 \mathrm{a}$ & $7.72 \mathrm{a}$ & $2.68 \mathrm{a}$ & $0.02 \mathrm{~b}$ & $0.79 \mathrm{~b}$ & $0.00 \mathrm{a}$ \\
\hline \multirow[t]{3}{*}{ S. nipponica } & Control & $0.12 \mathrm{~b}$ & $8.34 \mathrm{c}$ & $1.53 \mathrm{c}$ & $14.96 \mathrm{~b}$ & $3.41 \mathrm{a}$ & $7.97 \mathrm{a}$ & $3.41 \mathrm{a}$ & $0.03 \mathrm{~b}$ & $0.24 \mathrm{c}$ & $0.01 \mathrm{a}$ \\
\hline & EC 3 & $0.43 \mathrm{~b}$ & $11.49 \mathrm{~b}$ & $7.26 \mathrm{~b}$ & $14.42 \mathrm{~b}$ & $3.21 \mathrm{a}$ & $7.84 \mathrm{ab}$ & $3.17 \mathrm{a}$ & $0.04 \mathrm{~b}$ & $0.57 \mathrm{~b}$ & $0.00 \mathrm{a}$ \\
\hline & EC 6 & $2.57 \mathrm{a}$ & $15.83 \mathrm{a}$ & $21.10 \mathrm{a}$ & $17.46 \mathrm{a}$ & $3.53 \mathrm{a}$ & $7.02 \mathrm{~b}$ & $3.01 \mathrm{a}$ & $0.06 \mathrm{a}$ & $0.91 \mathrm{a}$ & $0.01 \mathrm{a}$ \\
\hline \multirow[t]{3}{*}{ S. thunbergii } & Control & $0.09 \mathrm{~b}$ & $9.17 \mathrm{~b}$ & $0.49 \mathrm{c}$ & $15.65 \mathrm{~b}$ & $2.74 \mathrm{~b}$ & $6.90 \mathrm{~b}$ & $2.73 \mathrm{ab}$ & $0.04 \mathrm{c}$ & $0.65 \mathrm{~b}$ & $0.00 \mathrm{~b}$ \\
\hline & EC 3 & $0.39 \mathrm{~b}$ & $14.51 \mathrm{a}$ & $7.95 \mathrm{~b}$ & $18.04 \mathrm{~b}$ & $3.18 \mathrm{~b}$ & $7.66 \mathrm{~b}$ & $2.50 \mathrm{~b}$ & $0.06 \mathrm{~b}$ & $1.28 \mathrm{a}$ & $0.00 \mathrm{~b}$ \\
\hline & EC 6 & $8.96 \mathrm{a}$ & $15.39 \mathrm{a}$ & $33.98 \mathrm{a}$ & $24.83 \mathrm{a}$ & $4.39 \mathrm{a}$ & $11.66 \mathrm{a}$ & $3.09 \mathrm{a}$ & $0.09 \mathrm{a}$ & $1.00 \mathrm{a}$ & $0.01 \mathrm{a}$ \\
\hline Species & & $* * *$ & $* * *$ & $* * *$ & $* * *$ & $* * *$ & $* * *$ & $* * *$ & $* * *$ & $* * *$ & $* *$ \\
\hline
\end{tabular}

${ }^{\mathrm{z}}$ Saline solution was created by adding sodium chloride $(\mathrm{NaCl})$ and calcium chloride $\left(\mathrm{CaCl}_{2}\right)$ to the nutrient solution.

${ }^{\mathrm{y}} \mathrm{Within}$ species, means with the same lowercase letters within a column and dependent variables are not significantly different among treatments according to Tukey's method for multiplicity at $\alpha=0.05$.

NS, $* * *, * * *$ Nonsignificant or significant at $P<0.05,0.01$, or 0.001 , respectively. 
increased $\mathrm{Cu}^{2+}$ concentrations by $14 \%$ and $45 \%$, respectively, compared with the control. All spirea species irrigated with saline solution at ECs of 3.0 and $6.0 \mathrm{dS} \cdot \mathrm{m}^{-1}$ had leaf $\mathrm{S}$ concentrations similar to that of the control, with the exception of $S$. thunbergii, which had a $13 \%$ greater $\mathrm{S}$ concentration at an EC of $6.0 \mathrm{dS} \cdot \mathrm{m}^{-1}$ (Table 6). Increasing salinity did not impact $\mathrm{Fe}^{3+}$ and $\mathrm{Al}^{3+}$ concentrations in leaves of all spirea species tested (data not shown). Mineral nutrient imbalance induced by excessive $\mathrm{Na}^{+}$and $\mathrm{Cl}^{-}$uptake has been reported to result in nutritional disorders and reduced plant quality (Grattan and Grieve, 1999). However, in this study, no visible nutrient deficiency was observed during the entire experimental period. These results suggest that the concentrations of the aforementioned mineral nutrients are still in normal ranges.

In conclusion, plant growth and photosynthesis of five spirea species reduced with varying responses to saline water irrigation, especially at an EC of $6.0 \mathrm{dS} \cdot \mathrm{m}^{-1}$. Spireae thunbergii was the most salt-sensitive species because all plants were dead at 8 weeks after the start of treatment. Slight-to-moderate foliar salt damage occurred on $S$. japonica, S. betulifolia, and $S$. nipponica, whereas severe foliar salt damage occurred on $S$. media. Regardless of the species, both $\mathrm{Na}^{+}$and $\mathrm{Cl}^{-}$concentrations increased along with increasing salinity levels, but the actual values of $\mathrm{Cl}^{-}$ions in the leaf were greater than those of $\mathrm{Na}^{+}$ions, indicating that foliar salt damage and decreased plant growth and photosynthesis might be mainly induced by the $\mathrm{Cl}^{-}$ions accumulated in the spirea leaves. These results could help nursery producers and landscape professionals with plant selection for sites where low-quality water may be used for irrigation.

\section{Literature Cited}

Appleton, B., V. Greene, A. Smith, S. French, B. Kane, L. Fox, A. Downing, T. Gilland, and D. Close. 2015. Trees and shrubs that tolerate saline soils and salt spray drift. Virginia Tech and Virginia State Univ. Coop. Ext. Publication 430-431.

Altland, J.E., J.C. Locke, and C.R. Krause. 2014. Influence of pine bark particle size and $\mathrm{pH}$ on cation exchange capacity. HortTechnology 24:554-559.

Beckerman, J. and B.R. Lerner. 2009. Salt damage in landscape plants. Purdue Univ. Coop. Ext. 412.

Carter, C.T. and C.M. Grieve. 2006. Salt tolerance of floriculture crops, p. 279-287. In: M.A. Khan and D.J. Weber (eds.). Ecophysiology of high salinity tolerant plants. Springer Science + Business Media, Dordrecht, The Netherlands.

Cavins, T.J., B.E. Whipker, and W.C. Fonteno. 2008. Pourthru: A method for monitoring nutrition in the greenhouse. Acta Hort. 779:289-298.

Chen, J., Y. Wang, A. Paudel, and Y. Sun. 2019 Comparing the salt tolerance of three landscape plants using a near-continuous gradient dosing system. HortTechnology 29:611-618.

Chen, L., Y. Sun, G. Niu, Q. Liu, and J. Altland. 2017. Relative salt tolerance of eight japanese barberry cultivars. HortScience 52:1810-1815.

Dirr, M.A. 2009. Manual of woody landscape plants: Their identification, ornamental characteristics, culture, propagation and uses. 6th ed. Stipes Publishing, Champaign, IL.

Gavlak, R.G., D.A. Horneck, and R.O. Miller 1994. Plant, soil, and water reference methods for the western region. Western Regional Extension Publication (WREP) 125.

Grattan, S.R. and C.M. Grieve. 1999. Salinity mineral nutrient relations in horticultural crops. Scientia Hort. 78:127-157.

Jull, L.G. 2009. Winter salt injury and salt-tolerant landscape plants. Univ. Wisconsin Coop. Ext. A3877.

Khan, G., F. Zhang, Q. Gao, P. Fu, R. Xing, J. Wang, H. Liu, and S. Chen. 2016. Phylogenetic analyses of Spiraea (Rosaceae) distributed in the Qinghai-Tibetan Plateau and adjacent regions: Insights from molecular data. Plant Syst. Evol. 302:11-21.

Liu, Q., Y. Sun, G. Niu, J. Altland, L. Chen, and L. Jiang. 2017. Morphological and physiological responses of ten ornamental taxa to saline water irrigation. HortScience 52:1816-1822.

Marosz, A. 2004. Effect of soil salinity on nutrient uptake, growth and decorative value of four ground cover shrubs. J. Plant Nutr. 27:977989.

Munns, R. and M. Tester. 2008. Mechanisms of salinity tolerance. Annu. Rev. Plant Biol. 59:651-681.

Navarro, A., S. Bañón, W. Conejero, and M. Sánchez-Blanco. 2008. Ornamental characters, ion accumulation and water status in Arbutus unedo seedlings irrigated with saline water and subsequent relief and transplanting. Environ. Exp. Bot. 62:364-370.

Niu, G. and R.I. Cabrera. 2010. Growth and physiological responses of landscape plants to saline water irrigation: A review. HortScience 45: $1605-1609$.

Niu, G., T. Starman, and D. Byrne. 2013. Responses of growth and mineral nutrition of garden roses to saline water irrigation. HortScience 48:756-761.

Stanton, K.M. and M.V. Mickelbart. 2014. Maintenance of water uptake and reduced water loss contribute to water stress tolerance of Spiraea alba Du Roi and Spiraea tomentose L. Hort. Res. 1:14033.

Sun, Y., G. Niu, and C. Perez. 2015. Relative salt tolerance of seven Texas Superstar ${ }^{\circledR}$ perennials. HortScience 50:1562-1566.

Taiz, L. and E. Zeiger. 2015. Plant physiology and development. 6th ed. Sinauer Assoc., Publ., Sunderland, MA.

U.S. Department of Agriculture. 2015. 2014 Census of horticultural specialties, Table 25. Washington, DC. 20 Dec. 2019. <https://www.agcensus. usda.gov/Publications /2012/Online_Resources/ Census_of_Horticulture_Specialties/hortic_1_004_ 004.pdf $>$.

Wang, Y., L. Li, Y. Sun, and X. Dai. 2019a. Relative salt tolerance of seven japanese spirea cultivars. HortTechnology 29:367-373.

Wang, Y., Y. Sun, G. Niu, C. Deng, Y. Wang, and J. Gardea-Torresdey. 2019b. Growth, gas exchange, and mineral nutrients of ornamental grasses irrigated with saline water. HortScience 54:1840-1846.

Wright, R.D. 1986. The pour-through nutrient extraction procedure. HortScience 21:227229.

Wu, S., Y. Sun, and G. Niu. 2016. Morphological and physiological responses of nine ornamental species to saline irrigation water. HortScience 51:285-290. 